\title{
Pengaruh Pemberian Pupuk Organik Urin Kelinci terhadap Pertumbuhan Tanaman Kangkung Darat (Ipomoea reptans)
}

\section{The Effect of Rabbit Urine Organic Fertilizer on The Growth of Land Kale Plants (Ipomoea reptans)}

\author{
Via Rahmatul Ummah, David Septian Sumanto Marpaung* \\ Program Studi Teknik Biosistem, Jurusan Teknologi Produksi dan Industri \\ Institut Teknologi Sumatera \\ *Korespondensi penulis, E-mail: david.marpaung@tbs.itera.ac.id
}

\begin{abstract}
The use of organic fertilizer is one solution to solve the problem of lack of nutrients considering the sustainability aspect. Rabbit droppings are obtained from rabbit breeders at P4S Agro Cendekia Bangunrejo. The study was conducted in July 2021 at P4S Agro Cendekia Bangunrejo. Liquid organic fertilizer was made by two different methods namely Y1 (a mixture of 10 liters of rabbit urine, 150 grams of brown sugar and 0.2 liters of EM3) with a fermentation time of 7 days and a pH of 7.5 and Y2 (a mixture of 10 liters of rabbit urine, 150 grams of brown sugar, 0.2 liters of EM3 and bamboo root) with a fermentation time of 6 days and a $\mathrm{pH}$ of 7.3. There were three treatments, namely $P 1$ as an experimental control (without the provision of liquid organic fertilizer), $P 2$ was given liquid organic fertilizer $Y 1, P 3$ was given liquid organic fertilizer $Y 2$. Each treatment was randomly taken as many as 5 samples. The growth parameter was analyzed after 10 days after planting are plant height, number of leaves, length of roots, and number of roots. It was obtained that the highest average plant height was $P 2$ treatment $(8.12 \mathrm{~cm})$. The average number of leaves was the largest in the P2 treatment, 5 stems. The average length of the highest root was in $P 3$ at $8.46 \mathrm{~cm}$. The average number of roots obtained in the $P 2$ treatment was 29 branches. Liquid organic fertilizer of rabbit urine affected the growth of kale plants.

Keywords: bio urine, effect of rabbit urine, growth
\end{abstract}

\begin{abstract}
ABSTRAK
Penggunaan pupuk organik merupakan salah satu solusi untuk menyelesaikan permasalahan minimnya unsur hara di dalam tanah, dengan memperhatikan aspek keberlanjutan. Kotoran kelinci didapatkan dari peternak kelinci di P4S Agro Cendekia Bangunrejo. Penelitian dilakukan pada bulan Juli 2021 di P4S Agro Cendekia Bangunrejo. Pupuk organik cair dibuat dengan dua metode yang berbeda yaitu $Y 1$ (campuran 10 liter urin kelinci, 150 gram gula merah dan 0,2 liter EM3) dengan waktu fermentasi selama 7 hari dan $\mathrm{pH}$ 7,5 serta Y2 (campuran 10 liter urin kelinci, 150 gram gula merah, 0,2 liter EM3 dan akar bambu) dengan waktu fermentasi selama 6 hari dan $\mathrm{pH} 7$,3. Terdapat tiga perlakuan yaitu $\mathrm{P} 1$ sebagai kontrol percobaan (tanpa pemberian pupuk organik cair), P2 diberi pupuk organik cair $\mathrm{Y} 1, \mathrm{P} 3$ diberi pupuk organik cair $\mathrm{Y} 2$. Masing-masing perlakuan diambil secara acak sebanyak 5 sampel untuk dijadikan objek penelitian. Parameter pertumbuhan tanaman kangkung yang dianalisis setelah 10 hst (hari setelah tanam) yaitu tinggi tanaman, jumlah daun, panjang akar dan jumlah akar. Dari data penelitian yang didapatkan yaitu rata-rata tinggi tanaman tertinggi ada pada perlakuan P2 dengan nilai sebesar $8,12 \mathrm{~cm}$. Ratarata jumlah daun terbanyak ada pada perlakuan P2 sebanyak 5 batang. Rata-rata panjang akar tertinggi ada pada P3 sebesar $8,46 \mathrm{~cm}$. Rata-rata jumlah akar terbanyak diperoleh pada perlakuan P2 sebanyak 29 cabang. Pupuk organik cair urin kelinci berpengaruh terhadap pertumbuhan tanaman kangkung.

Kata kunci: biourine, efek urin kelinci, pertumbuhan
\end{abstract}




\section{PENDAHULUAN}

Seiring dengan perkembangan zaman, jumlah pertambahan penduduk di Indonesia mengalami peningkatan. Pertambahan penduduk mengakibatkan kebutuhan produksi pangan menjadi semakin banyak. Sementara itu, terjadinya peralihan fungsi lahan pertanian yang mengalami pergeseran menjadi lahan industri, pemukiman, maupun fasilitas umum yang lainnya menyebabkan lahan pertanian semakin sempit dan terbatas. Padahal produktivitas sangat berpengaruh dengan luasnya lahan yang digunakan. Sehingga faktor adanya lahan pertanian sangat berpengaruh penting karena jika keberadaannya menurun maka akan mengganggu jumlah produksi pangan yang dihasilkan (Mustopa dan Santosa 2011). Oleh karena itu, perlunya sistem manajemen yang tepat menjadi hal yang juga dibutuhkan untuk mengatasi masalah-masalah pada sektor pertanian. Meningkatnya pertambahan jumlah penduduk juga menimbulkan masalah lain seperti meningkatnya jumlah limbah yang dihasilkan. Namun, sampai sekarang ini pengelolaan limbah masih terus dikembangkan. Salah satu cara yaitu dengan mengelola limbah tersebut menjadi pupuk organik yang dapat digunakan masyarakat kembali.
Sampai saat ini, luasan tanah pertanian yang tersedia cenderung semakin berkurang dan menyempit. Selain itu, kondisi kualitas tanah pertanian cenderung ikut menurun seiring terpakainya tanah pada lahan pertanian tersebut. Salah satu upaya yang dapat diusaakan untuk mengurangi degradasi lahan adalah dengan penggunaan pupuk organik. Penggunaan pupuk organic diharapkan mampu mengembalikan kesuburan tanah yang telah menurun. Pupuk organik bisa menjadi pilihan yang tepat untuk memperbaiki sifat fisik, kimia, dan biologi tanah serta membuat lahan pertanian menjadi sehat dan menghasilkan produk pertanian secara organik.

Penggunaan pupuk organik cair yang berasal dari limbah biomassa telah banyak digunakan sebelumnya. Beberapa penelitian sebelumnya seperti, pupuk organik cair dari limbah perikanan (Zahroh et al. 2018), pupuk organik cair dari limbah pertanian (Hidayat dan Suharyana, 2019; Muningsih dan Ciptadi, 2018), pupuk organik cair dari limbah peternakan (Nubriama et al. 2019) telah diaplikasikan ke beberapa komoditas pertanian untuk meningkatkan nilai produksi. Berdasarkan hal tersebut, pupuk organik cari yang berasal dari limbah biomassa berpotensi sebagai 
peningkat nilai produksi di beberapa komoditas pertanian dan berpotensi dikomersialisasikan.

Di P4S Agro Cendekia Bangunrejo, Lampung terdapat suatu usaha budidaya kelinci pedaging yang sudah menjalankan kegiatan bisnisnya sejak lama. Namun, pemanfaatan limbah dari kelinci masih sebatas pada produk daging. Urin dari kelinci belum mendapatkan fokus untuk pengolahan lebih lanjut menjadi suatu produk. Potensi urin kelinci menjadi pupuk organik dapat ditemukan pada penelitian sebelumnya yang menggunakannya untuk meningkatkan pertumbuhan tanaman kakao (Rosniawaty et al. 2015), tanaman tomat (Sembiring et al. 2017), tanaman sawi (Cholisoh et al. 2018), tanaman caisim (Kristanto dan Aziz 2019), dan tanaman wortel (Sundari 2019). Namun hingga kini, penggunaan pupuk organik cair urin kelinci untuk peningkatan nilai produksi tanaman kangkong masih optimal. Penelitian ini bertujuan untuk mengetahui pengaruh pupuk organik cair urin kelinci terhadap pertumbuhan tanaman kangkung.

\section{METODE}

\section{Persiapan Pupuk Organik Cair Urin}

Kelinci

Penelitian ini dilakukan di P4S Agro Cendekia Bangunrejo dengan waktu pelaksanaan tanggal 2 Juni-21 Juli 2021. Pengamatan dilakukan pada jenis kangkung darat dengan parameter yang diukur meliputi pertumbuhan dari tinggi tanaman, jumlah daun, panjang akar dan jumlah akar sebagai respon dari pemberian pupuk organik urin kelinci. Adapun formulasi pupuk organik cair urin kelinci yang digunakan dalam penelitian ini dapat dilihat pada Tabel 1.

Tabel 1 Formulasi pupuk organik cair urin kelinci

\begin{tabular}{|c|c|}
\hline Kode Perlakuan & Perlakuan \\
\hline Y1 & $\begin{array}{l}\text { Campuran } 10 \text { liter urin kelinci, gula merah } 150 \text { gram, dan 0,2 liter } \\
\text { EM3 }\end{array}$ \\
\hline Y2 & $\begin{array}{l}\text { Campuran } 10 \text { liter urin kelinci, gula merah, } 0,2 \text { liter EM3, dan akar } \\
\text { bambu }\end{array}$ \\
\hline
\end{tabular}

\section{Pemberian Pupuk Organik Cair Urin} Kelinci ke Tanaman Kangkung

Setelah ketiga jenis pupuk cair organik sudah siap, penelitian dilanjutkan untuk mengamati pertumbuhan dari tanaman kangkung pada 10 hari setelah tanam, penelitian kali ini menggunakan tiga perlakuan pada empat petak tanaman yang masing-masing petak terdapat 20 polibag yang akan ditanami tanaman kangkung sehingga total jumlah sampel 
yang digunakan pada penelitian kali ini berjumlah 80 sampel. Setiap polibag berisi tanah dengan tambahan feses kelinci yang diletakkan di atas permukaan tanah dengan berat yang sama yaitu 50 gram feses kelinci di setiap satu polibag, jumlah tanah dan feses kelinci merupakan varibel kontrol pada penelitian kali ini. Adapun perlakuan pemberian pupuk organik cair urin kelinci dapat dilihat pada Tabel 2.

Tabel 2 Perlakuan pemberian pupuk organik cair urin kelinci

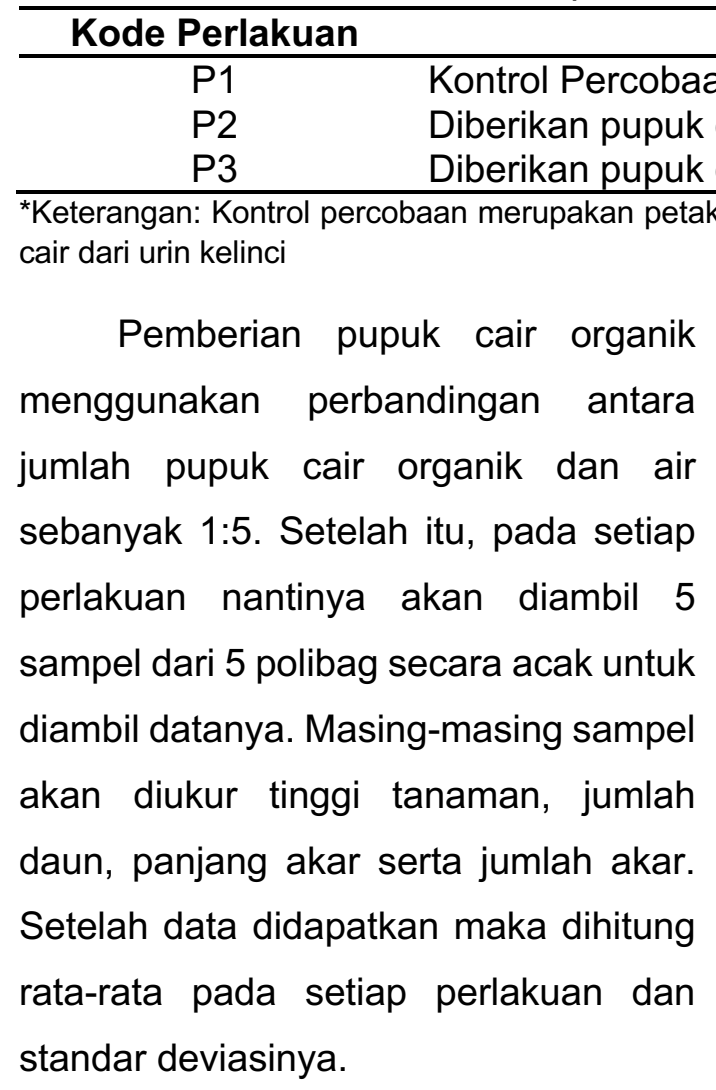

HASIL DAN PEMBAHASAN

Pertumbuhan Tinggi Tanaman Kangkung

\section{Perlakuan}

\section{Perlakua}




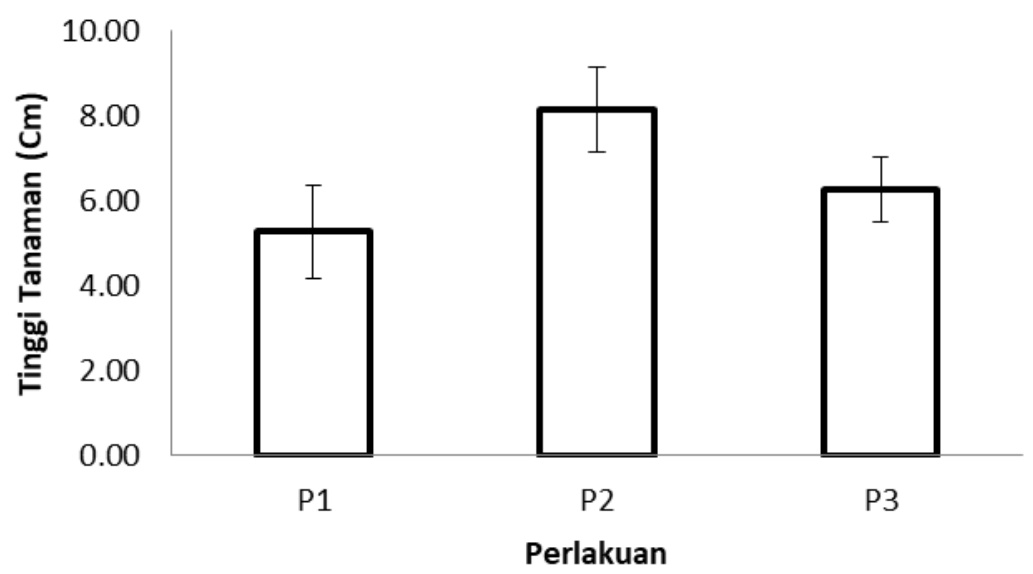

Gambar 1 Perbedaan tinggi tanaman pada P1, P2, dan P3

Hasil pengamatan menunjukkan bahwa data rata-rata tinggi tanaman yang didapatkan tinggi tanaman terendah berada pada $\mathrm{P} 1$ tanaman kangkung tidak diberikan pupuk organik cair dan data tertinggi berada pada P3 yaitu pada tanaman kangkung diberikan pupuk organik cair dari percampuran urin kelinci yang ditambahkan dengan gula merah dan aktivator berupa EM3. Tanaman akan terus tumbuh apabila nutrisinya tercukupi, pertumbuhan tanaman dapat dipengaruhi oleh faktor lingkungan, fisiologi ,dan genetik tanaman (Nurrohman et al. 2015).

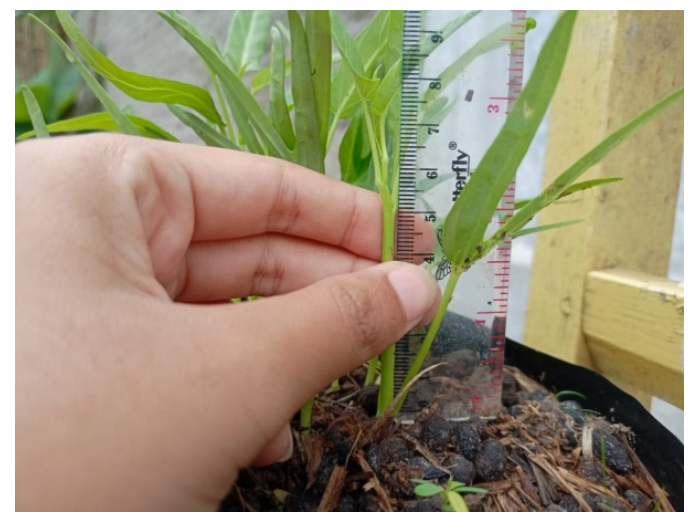

Gambar 2 Pengukuran tinggi tanaman kangkung

Penambahan Jumlah Daun Tanaman

\section{Kangkung}

Daun merupakan bagian tanaman yang berfungsi sebagai tempat sintesis makanan untuk kebutuhan tanaman maupun sebagai cadangan makanan untuk tanaman. Dalam proses fotosintesis diperlukan aerasi yang baik pada media tanam supaya mendukung akar tanaman dalam menyerap air dan 
unsur hara secara optimal yang maka tempat yang digunakan sebagai selanjutnya akan diteruskan ke tanaman untuk proses metabolisme yang proses fotosintesis akan lebih banyak berperan dalam pertambahan luas dan menghasilkan produk fotosintesis daun. Sehingga, semakin banyak yang lebih banyak juga (Simorangkir et jumlah daun yang ada pada tanaman al. 2017).

Tabel 4 Jumlah daun tanaman kangkung pada setiap perlakuan

\begin{tabular}{|c|c|c|c|c|c|c|c|}
\hline \multirow[b]{2}{*}{ Perlakuan } & \multicolumn{5}{|c|}{ Jumlah Daun (Unit) } & \multirow{2}{*}{$\begin{array}{c}\text { Rata- } \\
\text { Rata } \\
\text { (cabang) }\end{array}$} & \multirow{2}{*}{$\begin{array}{l}\text { Standar } \\
\text { Deviasi } \\
\text { (cabang) }\end{array}$} \\
\hline & $\begin{array}{c}\text { Sampel } \\
1 \\
\end{array}$ & $\begin{array}{c}\text { Sampel } \\
2\end{array}$ & $\begin{array}{c}\text { Sampel } \\
3\end{array}$ & $\begin{array}{c}\text { Sampel } \\
4\end{array}$ & $\begin{array}{c}\text { Sampel } \\
5\end{array}$ & & \\
\hline P1 & 5,00 & 4,00 & 4,00 & 5,00 & 4,00 & 4 & 0,55 \\
\hline P2 & 4,00 & 5,00 & 5,00 & 5,00 & 5,00 & 5 & 0,45 \\
\hline P3 & 4,00 & 4,00 & 5,00 & 4,00 & 4,00 & 4 & 0,45 \\
\hline
\end{tabular}
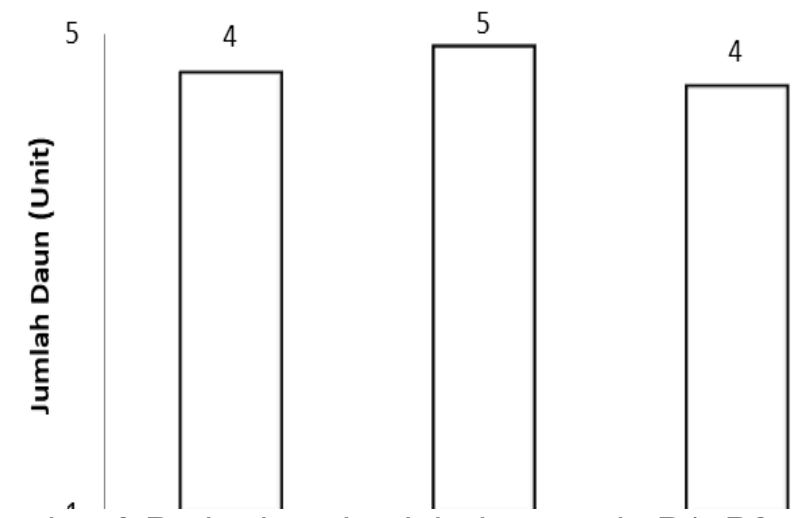

Gambar 3 Perbedaan jumlah daun pada P1, P2, dan P3

Berdasarkan data pada Tabel 4 dapat diketahui bahwa rata-rata jumlah daun pada setiap perlakuan tidak terlalu memiliki perbedaan yang signifikan. Pada P1 memiliki rata-rata jumlah daun sebanyak 4 batang dengan standar deviasi sebesar 0,55 batang, P2 memiliki rata-rata jumlah daun sebanyak
5 batang dengan standar deviasi sebesar 0,45 batang dan P3 memiliki rata-rata jumlah daun sebanyak 4 batang dengan standar deviasi sebesar 0,45 batang. Sehingga dapat disimpulkan P2 memiliki jumlah daun lebih banyak dibandingkan dengan perlakuan yang lainnya. 


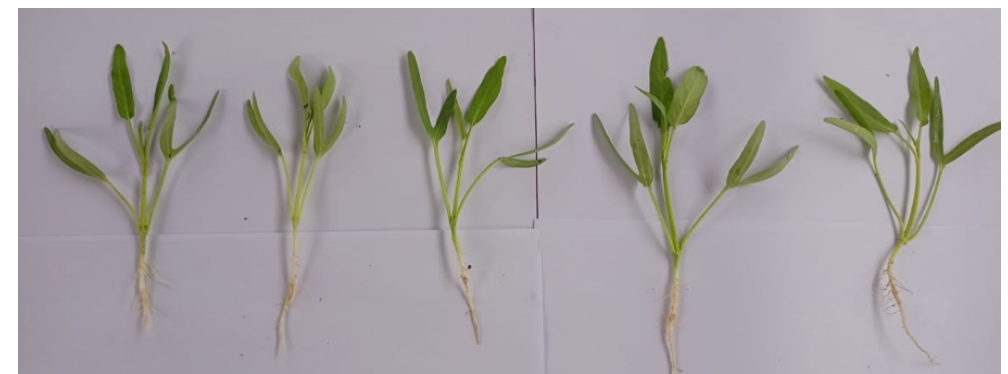

Gambar 4 Jumlah daun

Hasil penelitian Badan Penelitian

Ternak (Balitnak) pada tahun 2005 menjelaskan bahwa pada feses dan urin kelinci mengandung unsur N,P,K yang lebih tinggi $(2,72 ; 1,1$; dan $0,5 \%)$ dibandingkan dengan kotoran hewan ternak lainnya seperti kuda, sapi, kerbau, domba, ayam dan babi. Pada tanaman yang mendapatkan kebutuhan unsur hara yang terpenuhi akan dapat merangsang pertumbuhan daun baru. Jumlah nitrogen yang terpenuhi pada tanaman mendukung warna daun yang tumbuh akan lebih hijau. Penambahan nitrogen pada tanaman mendorong pertumbuhan organ-organ yang berkaitan dengan proses fotosintesis seperti daun (Gustia 2014). Sehingga jumlah daun pada P3 dapat diakibatkan oleh adanya proses aerasi yang baik sehingga metabolisme yang berperan dalam penambahan jumlah daun bekerja dengan baik dan jumlah nitrogen pada media tanam P3 lebih tercukupi jika dibandingkan dengan perlakuan lainnya.

\section{Pertumbuhan Panjang Akar \\ Tanaman Kangkung}

Pada pengukuran terhadap panjang akar tanaman didapatkan dan disajikan pada Tabel 5 bahwa P1 memiliki rata-rata panjang akar sebesar $7,68 \mathrm{~cm}$ dengan standar deviasinya sebesar $1.48 \mathrm{~cm}, \mathrm{P} 2$ memiliki rata-rata panjang akar sebesar $7,98 \mathrm{~cm}$ dengan standar deviasi sebesar $1,76 \mathrm{~cm}$ dan P3 memiliki rata-rata panjang akar sebesar $8,46 \mathrm{~cm}$ dengan standar deviasinya sebesar 1,69 cm. Dari data yang didapatkan, P3 memiliki rata-rata panjang akar yang lebih dominan dibandingkan dengan perlakuan yang lainnya. Panjang akar tanaman akan berpengaruh pada kemampuan akar dalam menyerap nutrisi yang ada di dalam tanah. Akar yang lebih panjang disebabkan oleh adanya nutrisi tanah yang cukup banyak sehingga mendorong kemampuan akar menyerap unsur hara dan nutrisi yang ada di dalam tanah. 
Tabel 5 Panjang akar tanaman kangkung pada setiap perlakuan

\begin{tabular}{|c|c|c|c|c|c|c|c|}
\hline \multirow[b]{2}{*}{ Perlakuan } & \multicolumn{5}{|c|}{ Panjang Akar (cm) } & \multirow[b]{2}{*}{$\begin{array}{l}\text { Rata-Rata } \\
\text { (cm) }\end{array}$} & \multirow{2}{*}{$\begin{array}{c}\text { Standa } \\
\text { Deviasi } \\
\text { (cm) }\end{array}$} \\
\hline & $\begin{array}{c}\text { Sampel } \\
1\end{array}$ & $\begin{array}{c}\text { Sampel } \\
2\end{array}$ & $\begin{array}{c}\text { Sampel } \\
3\end{array}$ & $\begin{array}{c}\text { Sampel } \\
4\end{array}$ & $\begin{array}{c}\text { Sampel } \\
5\end{array}$ & & \\
\hline P1 & 5,50 & 7,90 & 9,50 & 8,30 & 7,20 & 7,68 & 1,48 \\
\hline P2 & 6,70 & 9,80 & 10,00 & 6,90 & 6,50 & 7,98 & 1,76 \\
\hline P3 & 9,50 & 9,80 & 9,70 & 6,20 & 7,10 & 8,46 & 1,69 \\
\hline
\end{tabular}

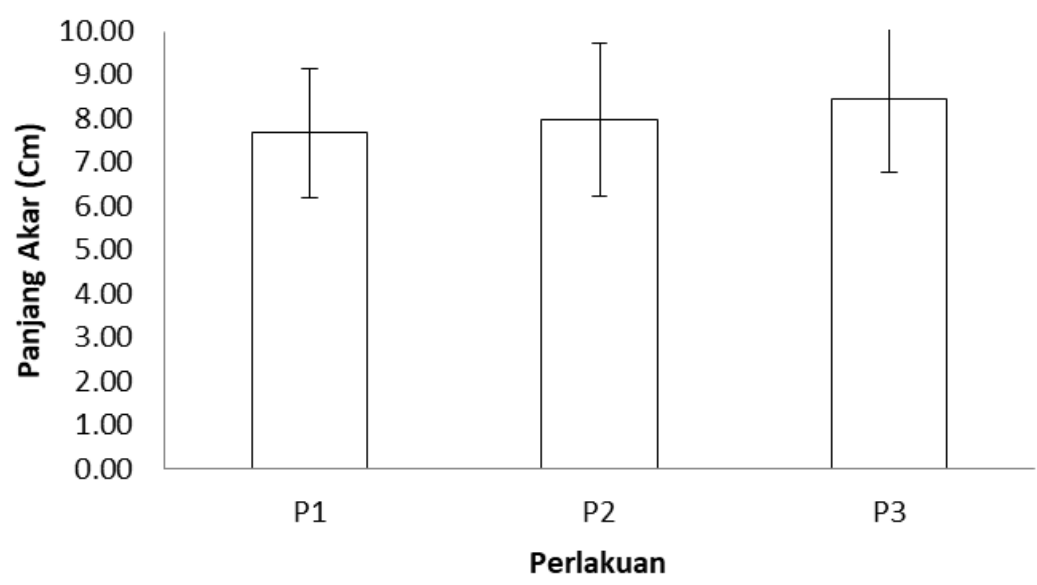

Gambar 5 Perbedaan panjang akar pada P1, P2, dan P3

Penambahan Jumlah Akar Tanaman

\section{Kangkung}

Pada pengukuran jumlah akar tanaman akar di setiap perlakuan dilakukan dengan menghitung jumlah akar yang ada pada satu batang tanaman secara manual. Berdasarkan data tabel di atas dapat diketahui bahwa pada P1 memiliki rata-rata jumlah akar sebanyak 21 akar dengan standar deviasi sebesar 6,11 akar, P2 memiliki jumlah akar sebanyak 29 akar dengan standar deviasi sebesar 5,54 akar dan P3 memiliki jumlah akar sebanyak 26 akar dengan standar deviasi sebesar 7,78 akar. Dapat diketahui bahwa jumlah akar P2 lebih banyak dibandingkan dengan perlakuan yang lainnya. Jumlah akar juga dipengaruhi oleh kemampuan akar dalam menyerap unsur hara dan nutrisi pada tanah sehingga keberadaan air dan unsur hara yang cukup akan memacu pertumbuhan akar tanaman.

Tabel 6 Jumlah akar tanaman kangkung dari setiap perlakuan

\begin{tabular}{|c|c|c|c|c|c|c|c|}
\hline \multirow{2}{*}{ Perlakuan } & \multicolumn{5}{|c|}{ Jumlah Akar } & \multirow{2}{*}{$\begin{array}{l}\text { Rata- } \\
\text { Rata }\end{array}$} & \multirow{2}{*}{$\begin{array}{l}\text { Standar } \\
\text { Deviasi }\end{array}$} \\
\hline & Sampel 1 & Sampel 2 & Sampel 3 & Sampel 4 & Sampel 5 & & \\
\hline P1 & 28 & 21 & 15 & 25 & 14 & 21 & 6.11 \\
\hline P2 & 32 & 25 & 36 & 29 & 22 & 29 & 5.54 \\
\hline P3 & 30 & 36 & 25 & 24 & 15 & 26 & 7.78 \\
\hline
\end{tabular}




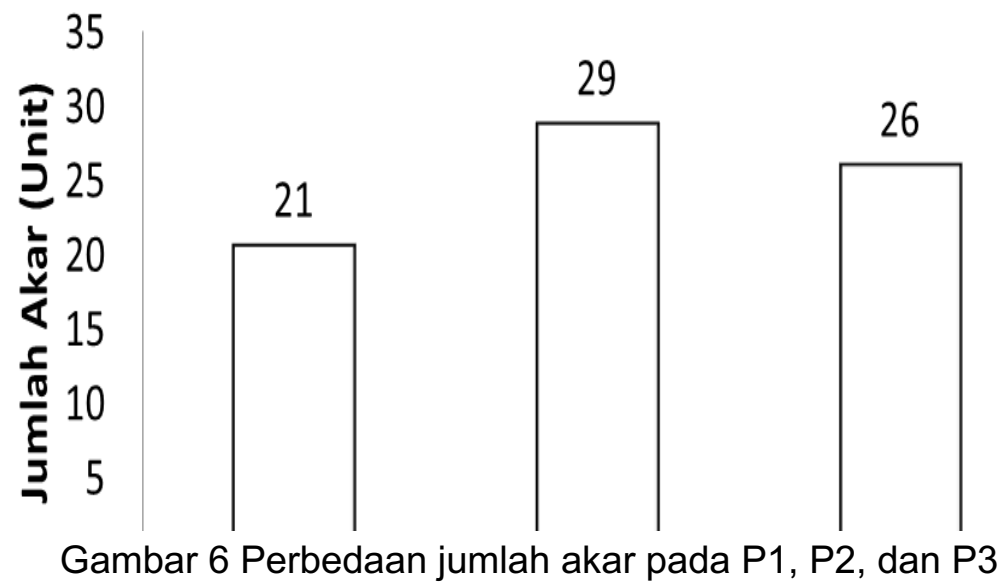

SIMPULAN

Pupuk organik cair urin kelinci memberi pengaruh terhadap pertumbuhan tanaman kangkung. Perlakuan terbaik dalam peningkatan pertumbuhan tanaman kangkung ditemukan pada campuran 10 liter urin kelinci, gula merah 150 gram, dan 0,2 liter EM3 dengan rata-rata tinggi tanaman $8,12 \mathrm{~cm}$, rata-rata jumlah daun 5 , rata-rata panjang akar $7,98 \mathrm{~cm}$, dan rata-rata jumlah akar 29. Penelitian lebih lanjut terhadap pengaruh konsentrasi pupuk organik cair urin kelinci akan memberikan pengetahuan yang lebih dalam tentang pupuk organik cair urin kelinci.
Cholisoh KN, Budiyanto S, Fuskhah E. 2018. Pertumbuhan dan produksi tanaman sawi (Brassica juncea I.) akibat pemberian pupuk urin kelinci dengan jenis dan dosis pemberian yang berbeda. Agro Complex. 2(3): 275-280.

Gustia H. 2014. Pengaruh Penambahan Sekam Bakar Pada Media Tanam Terhadap Pertumbuhan dan Produksi Tanaman Sawi (Brassica Juncea L.)', E-Journal Widya Kesehatan dan Lingkungan. 1(1): 12-17.

Hidayat O, Suharyana A. 2019. Pengaruh Dosis Pupuk Organik Cair Daun Lamtoro terhadap Pertumbuhan dan Hasil Tanaman Pakcoy (Brassica rapa L.) Varietas Nauli-F1. Paspalum: Jurnal IImiah Pertanian. 7(2): 57-63. http://dx.doi.org/10.35138/paspalu m.v7i2.118. 
Kristanto D, Aziz SA. 2019. Aplikasi Pupuk Organik Cair Urin Kelinci Meningkatan Pertumbuhan dan Produksi Caisim (Brassica juncea L.) Organik di Yayasan Bina Sarana Bakti, Cisarua, Bogor, Jawa Barat. Buletin Agrohorti. 7(3): 281-286.

Muningsih R, Ciptadi G. 2018. Potensi Limbah Cair Teh Hijau Sebagai Bahan Pupuk Organik Cair dan Pengaruhnya Terhadap Pertumbuhan Bibit Teh. Jurnal Agrin. 21(2): 140-145. Available at: http://dx.doi.org/10.20884/1.agrin.20 17.21.2.372.

Mustopa Z, Santosa PB. 2011. Analisis Faktor-Faktor yang Mempengaruhi Alih Fungsi Lahan Pertanian di Kabupaten Demak [Skripsi]. Semarang: Universitas Diponegoro.

Nubriama RA, Pane E, Hutapea S. 2019. Pengaruh Pemberian Pupuk Organik Cair Kandang Kelinci dan Kompos Limbah Baglog pada Pertumbuhan Bibit Kakao (Theobroma cacao I.) Di polibeg. Jurnal IImiah Pertanian (JIPERTA). 1(2): 143-152. Available at: http://dx.doi.org/10.31289/jiperta.v1i 2.88.

Nurrohman M, Suryanto A, Wicaksono KP. 2015. Penggunaan Fermentasi Ekstrak Paitan (Tithonia diversifolia L.) dan
Kotoran Kelinci Cair Sebagai Sumber Hara Pada Budidaya Sawi (Brassica juncea L.) secara Hidroponik Rakit Apung. Jurnal Produksi Tanaman. 2(8): 649657.

Rosniawaty $S$, Sudirja $R$, Afrianto $H$. 2015. Pemanfaatan Urin Kelinci dan Urin Sapi sebagai Alternatif Pupuk Organik Cair pada Pembibitan Kakao (Theobroma cacao L.). Jurnal Kultivasi. 14(1): 32-36. Available at: http://dx.doi.org/10.24198/kultivasi.v 14i1.12094.

Sembiring MY, Setyobudi L, Sugito Y. 2017. Pengaruh Dosis Pupuk Urin Kelinci terhadap Pertumbuhan dan Hasil Beberapa Varietas Tomat. Jurnal Produksi Tanaman. 5(1): 132139.

Simorangkir CA, Supriyanto A, Murdiono WE, Nihayati E. 2017. Pemberian Pupuk Urin Kelinci (Leporidae) dan $\mathrm{KNO} 3$ pada Pertumbuhan dan Hasil Tanaman Stroberi (Fragaria sp.). Jurnal Produksi Tanaman. 5(5): 782790.

Sundari, S., 2019. Analisis Perbandingan antara Pupuk Organik Urin Kelinci dengan Pupuk Nonorganik (NPK Mutiara) terhadap Pendapatan dan Hasil Panen Wortel di Desa Hanakau, Kabupaten 
Lampung Barat. Industrika: Jurnal Industrika. 3(1): 24-35.

Zahroh F, Kusrinah K, Setyawati SM.

2018. Perbandingan Variasi

Konsentrasi Pupuk Organik Cair

dari Limbah Ikan terhadap

Pertumbuhan Tanaman Cabai

Merah (Capsicum annum L.). Al-

Hayat: Journal of Biology and

Applied Biology. 1(1): 50-57.

Available at:

http://dx.doi.org/10.21580/ah.v1i1.

2687. 